\title{
Efficient Synthesis of Isoquinoline Derivatives through Sequential Cyclization-Deoxygenation Reaction of 2-Alkynylbenzaldoximes
}

\author{
Mojtaba Ayoubia \\ Ali Nikbakht ${ }^{a}$ \\ Kamran Amiria \\ Alireza Abbasi Kejania (D) \\ Hossein Zahedian Tejeneki ${ }^{\text {(D) }}$ \\ Saeed Balalaie ${ }^{* a, b}$ (D) \\ a Peptide Chemistry Research Institute , K. N. Toosi University of \\ Technology, P. O. Box 15875-4416, Tehran, Iran \\ balalaie@kntu.ac.ir \\ ${ }^{b}$ Medical Biology Research Center, Kermanshah University of \\ Medical Sciences, Kermanshah, Iran \\ Dedicated to Professor Issa Yavari for his outstanding contributions to Chemistry in Iran \\ Published as part of the Virtual Collection in Honor of Prof. Issa Yavari
}
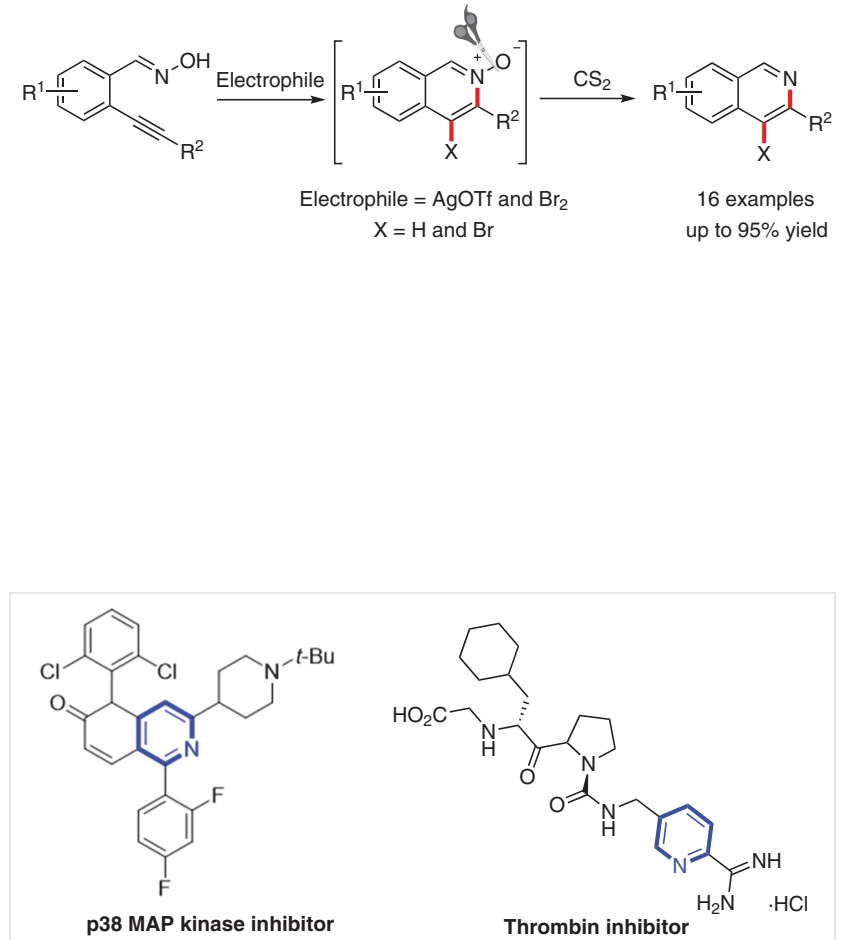

Abstract We describe a novel, simple, robust, and efficient cyclization/deoxygenation approach for the synthesis of functionalized isoquinoline derivatives. Over the course of continued studies on o-alkynylbenzaldoxime cyclization reactions, the formation of cyclic nitrones through 6-endo-dig cyclization was achieved using silver triflate or bromine as an electrophile, and subsequently, the deoxygenation process was carried out in the presence of $\mathrm{CS}_{2}$ in good to high yields.

Key words 2-alkynylbenzaldoxime, cyclization/deoxygenation, isoquinoline, silver triflate, bromine, carbon disulfide

In recent years, oxygen-atom-transfer reactions of heteroaromatic $N$-oxides have received much attention in modern chemistry due to their great potential in the synthesis of natural products, bioactive molecules, and applications in industrial processes. ${ }^{1}$ As illustrated in Figure 1, deoxygenation of heteroaromatic $\mathrm{N}$-oxides is the key step for the synthesis of a number of bioactive molecules such as p38 MAP kinase, ${ }^{2}$ thrombin, ${ }^{3}$ tyrosine kinase, and sodium channel ${ }^{4}$ inhibitors.

Various procedures and conditions have been reported for the reduction of $\mathrm{N}$-heteroarene $\mathrm{N}$-oxides such as photocatalytic reactions, ${ }^{5}$ electrochemical reactions, ${ }^{6}$ sulfur sources, ${ }^{7}$ trivalent phosphorus compounds, ${ }^{8}$ hydride reagents, ${ }^{9}$ and metal-catalyzed ${ }^{10}$ reactions. Nevertheless, some of these processes have serious disadvantages such as utilizing expensive and complex metal catalysts and reagents, high reaction temperature, low yields, harsh reac-
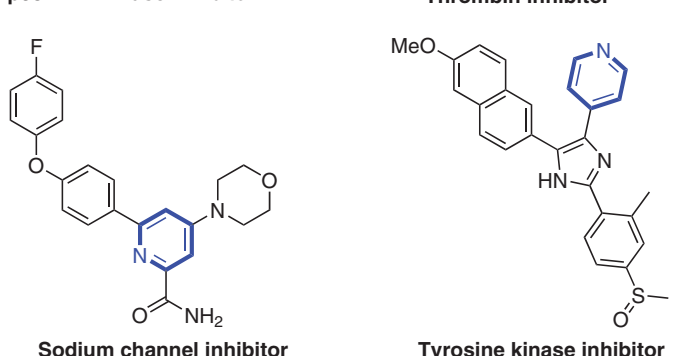

Figure 1 Bioactive compounds containing deoxygenation step

tion conditions, extended reaction times, and difficult workup. ${ }^{11}$

Due to the importance and broad application of the isoquinoline moiety in medicinal chemistry and materials science, numerous approaches such as the Bischler-Napieralski reaction ${ }^{12}$ for the synthesis of substituted isoquinolones have been described and deoxygenation of isoquinoline $\mathrm{N}$ oxides is an efficient way to achieve this core. ${ }^{11 e}$ On the other hand, the intramolecular annulation reaction of 2-alkynylbenzaldoximes with two active sites, which can be obtained by simple condensation of $o$-alkynylbenzaldehydes with hydroxylamine, is one of the most common methods among various strategies to access isoquinoline $\mathrm{N}$-oxides (Scheme 1). ${ }^{13}$ 

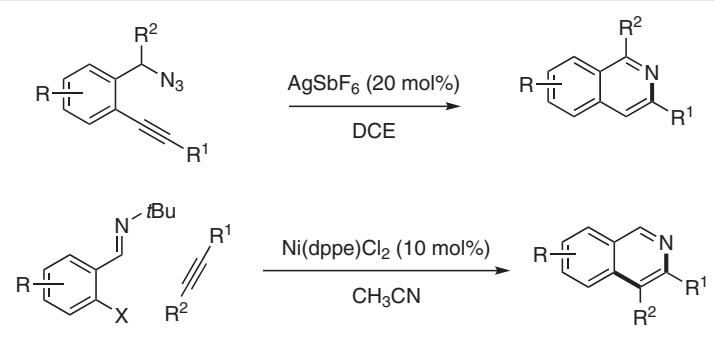

$$
\text { DMF }
$$

Scheme 1 Some strategies for the synthesis of isoquinolines via cyclization onto an alkyne

As part of our ongoing studies on the synthesis of functionalized 2-alkynylbenzaldoximes and their applications in a variety of tandem reactions,${ }^{14}$ we wish to report a novel and efficient method for the synthesis of isoquinolines via deoxygenation of in situ generated isoquinoline $\mathrm{N}$-oxide using carbon disulfide as a reductant under mild reaction conditions (Scheme 2).

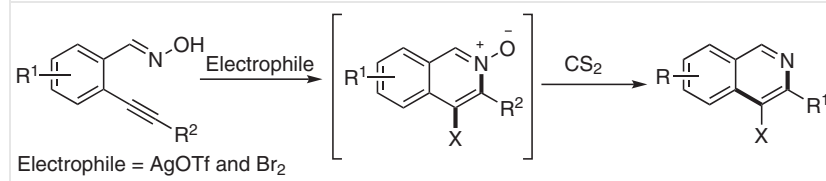

$\mathrm{X}=\mathrm{H}$ and $\mathrm{Br}$

Scheme 2 Representative sequential cyclization-deoxygenation reactions for the synthesis of isoquinoline derivatives

Initially, we investigated the cyclization-deoxygenation reactions of $o$-(phenylethynyl)benzaldoxime (1a) as a model substrate in the presence of a catalytic amount of $\mathrm{AgNO}_{3}$ and $\mathrm{CS}_{2}$ in DMF at $40{ }^{\circ} \mathrm{C}$, which afforded the desired product 2a in $33 \%$ isolated yield (Table 1, entry 1). Subsequently, the influence of the various transition-metal catalysts on the cyclization reaction such as $\mathrm{AgOTf}, \mathrm{PPh}_{3} \mathrm{AuCl}$, In(OTf $)_{3}$, and $\mathrm{CuBr}$ was screened, in which AgOTf (10 mol\%) indicated the best catalytic activity (Table 1 , entries $1-5$ ). Then, solvent screening showed DMF to be the best choice (Table 1, entries 5-7). Next, several reaction temperatures were examied and showed that temperature had a significant effect on reaction yield (Table 1 , entries 5 and $8-11$ ) with a temperature of $60^{\circ} \mathrm{C}$ giving the best results. Increasing the temperature up to $100{ }^{\circ} \mathrm{C}$ led to a slight decrease in the yield of the desired product. Screening of different amounts of carbon disulfide revealed that the 1.2 equivalents of $\mathrm{CS}_{2}$ gave the best result (Table 1, entries 9 and 12-14).
Table 1 Optimization of Reaction Conditions for the Synthesis of $2 a$ in the Presence of $\mathrm{AgNO}_{3}$ and $\mathrm{CS}_{2}{ }^{\mathrm{a}}$

\begin{tabular}{|c|c|c|c|c|c|}
\hline Entry & $\begin{array}{l}\text { Metal catalyst } \\
\text { (10 mol\%) }\end{array}$ & $\begin{array}{l}\mathrm{CS}_{2} \\
\text { (equiv) }\end{array}$ & $\begin{array}{l}\text { Solvent } \\
(2 \mathrm{~mL})\end{array}$ & $\begin{array}{l}\text { Temp } \\
\left({ }^{\circ} \mathrm{C}\right)\end{array}$ & $\begin{array}{l}\text { Yield } \\
(\%)^{\mathrm{b}}\end{array}$ \\
\hline 1 & $\mathrm{AgNO}_{3}$ & 1.2 & DMF & 40 & 33 \\
\hline 2 & $\mathrm{PPh}_{3} \mathrm{AuCl}$ & 1.2 & DMF & 40 & 29 \\
\hline 3 & $\ln (\mathrm{OTf})_{3}$ & 1.2 & DMF & 40 & 35 \\
\hline 4 & $\mathrm{CuBr}$ & 1.2 & DMF & 40 & 33 \\
\hline 5 & AgOTf & 1.2 & DMF & 40 & 49 \\
\hline 6 & AgOTf & 1.2 & toluene & 40 & 28 \\
\hline 7 & AgOTf & 1.2 & DCE & 40 & 31 \\
\hline 8 & AgOTf & 1.2 & DMF & 50 & 63 \\
\hline 9 & AgOTf & 1.2 & DMF & 60 & 97 \\
\hline 10 & AgOTf & 1.2 & DMF & 80 & 95 \\
\hline 11 & AgOTf & 1.2 & DMF & 100 & 92 \\
\hline 12 & AgOTf & 0.8 & DMF & 60 & 70 \\
\hline 13 & AgOTf & 1 & DMF & 60 & 86 \\
\hline 14 & AgOTf & 1.5 & DMF & 60 & 97 \\
\hline
\end{tabular}

a Reaction conditions: 1 a ( $0.2 \mathrm{mmol}), \mathrm{CS}_{2}$ (1.2 equiv), AgOTf (10 mol\%), solvent $(2 \mathrm{~mL})$ for $6 \mathrm{~h}$.

${ }^{\mathrm{b}}$ Isolated yields.

With optimal reaction conditions in hand, the scope of the reaction was surveyed. To expand the diversity of the starting materials, a wide range of $o$-alkynylbenzaldoxime derivatives containing electron-withdrawing, electron-donating, and halogen groups substituted on the phenyl ring, as well as aliphatic and aromatic alkynes was synthesized in excellent yields. Subsequently, under optimized reaction conditions, the annulation-deoxygenation reaction of various substituted $o$-alkynylbenzaldoximes was examined and afforded the corresponding substituted isoquinolines in good to high yields. The observed results are shown in Scheme 3, and all structures were confirmed by ${ }^{1} \mathrm{H}$ and ${ }^{13} \mathrm{C}$ NMR and HRMS spectral analysis (see the Supporting Information).

In the second part of the work, activation of the alkyne moiety in the 2-alkynylbenzaldoxime skeleton was investigated employing $\mathrm{Br}_{2}$ instead of a transition-metal catalyst, and subsequent deoxygenation of isoquinoline $\mathrm{N}$-oxides was carried out in the presence of the carbon disulfide. After some screening and trials, the best results were obtained using $\mathrm{Br}_{2}$ (1.2 equiv) and $\mathrm{NaHCO}_{3}$ (1.2 equiv) in DMF at room temperature and carbon disulfide (1.2 equiv) in DMF at $60^{\circ} \mathrm{C}$. 


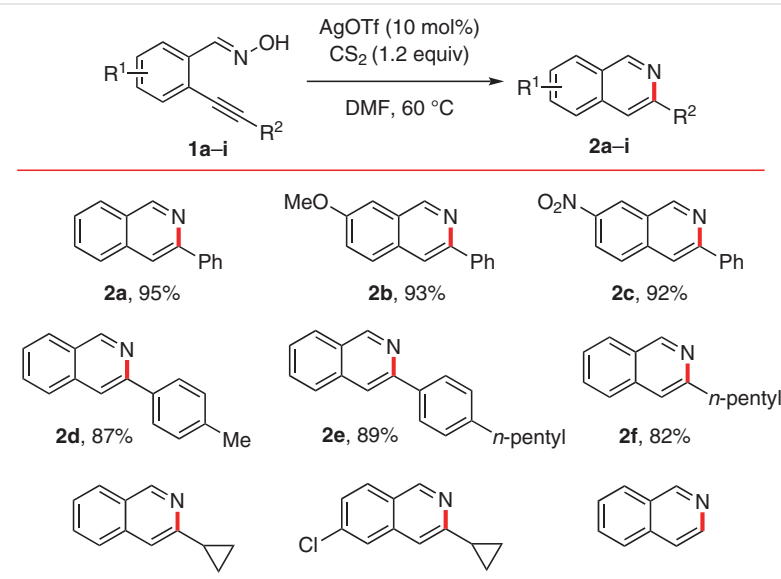

2g, $77 \%$

2h, $70 \%$

2i, $74 \%$

Scheme 3 Substrate scope for the isoquinoline skeletons $\mathbf{2 a - i}$. Reagents and conditions: $\mathbf{2 a - i}(0.2 \mathrm{mmol}), \mathrm{CS}_{2}$ (1.2 equiv), AgOTf $(10 \mathrm{~mol} \%)$, DMF $(2 \mathrm{~mL})$ at $60^{\circ} \mathrm{C}$. All products were characterized by ${ }^{1} \mathrm{H}$ and ${ }^{13} \mathrm{C}$ NMR spectroscopy and HRMS analysis.

The generality of the approach to produce the 4-bromo3-alkylisoquinoline derivatives was studied under these optimum reaction conditions. As illustrated in Scheme 4, a wide range of substituted 4-bromo-3-alkylisoquinolines bearing electron-donating and electron-withdrawing groups was synthesized in good to high yields.

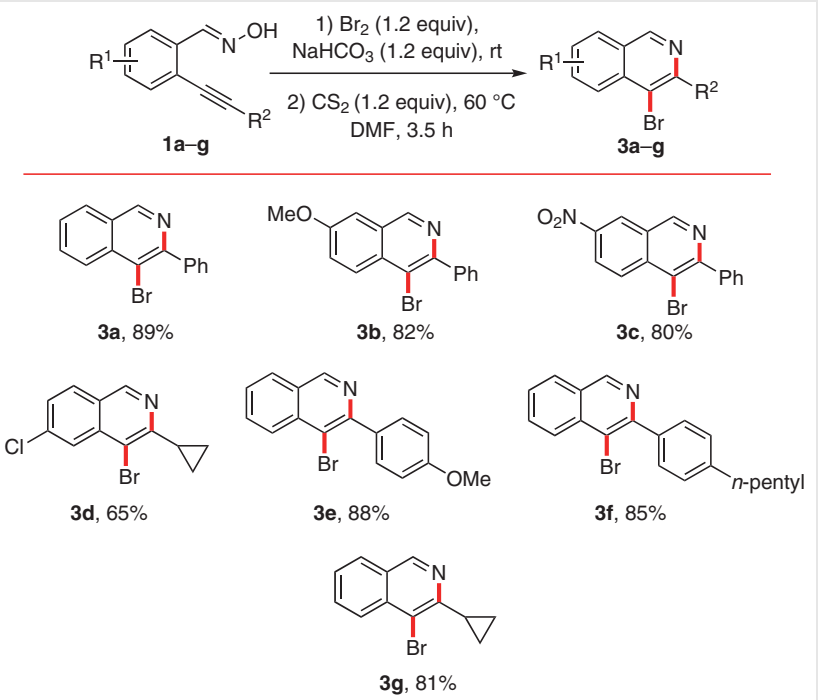

Scheme 4 Substrate scope for the 4-bromo-3-alkylisoquinoline skeletons $\mathbf{3 a - g}$. Reagents and conditions: $\mathbf{3 a}-\mathbf{g}(0.2 \mathrm{mmol}), \mathrm{Br}_{2}$ (1.2 equiv), $\mathrm{NaHCO}_{3}$ (1.2 equiv), $\mathrm{CS}_{2}$ (1.2 equiv), DMF ( $2 \mathrm{~mL}$ ) for $3.5 \mathrm{~h}$. In all cases, the reported yields are isolated yields.

According to the literature, ${ }^{15}$ the proposed reaction mechanism is as depicted in Scheme 5. In the presence of an electrophile, 6-endo-dig cyclization of the 2-alkynylbenzaldoxime by $\pi$-activation of alkyne moiety leads to the formation of the isoquinoline- $N$-oxides I. Then, $[3+2]$ dipo- lar cycloaddition of the isoquinoline $\mathrm{N}$-oxide with $\mathrm{CS}_{2}$ results in intermediate II. By homolytic cleavage of $\mathrm{N}-\mathrm{O}$ and $\mathrm{C}-\mathrm{S}$ bonds, the desired isoquinoline is obtained with COS and $\mathrm{S}$ as byproducts, according to the literature.

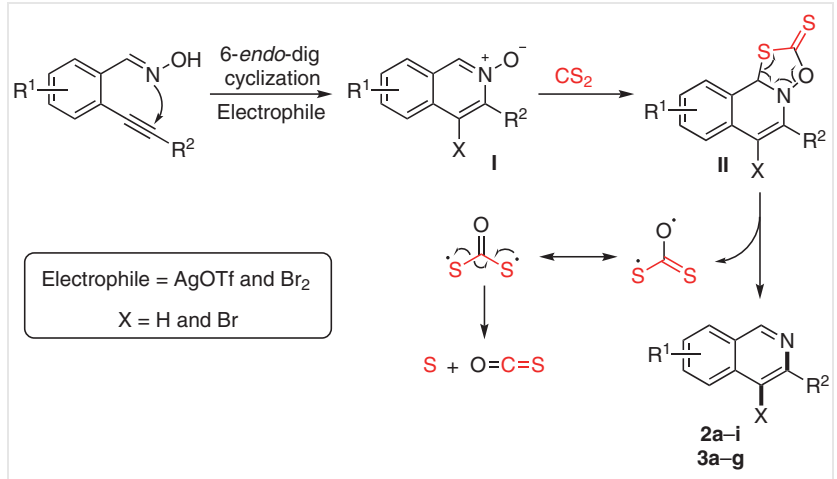

Scheme 5 A plausible reaction mechanism for the synthesis of $\mathbf{2 a - i}$ and $3 a-g$

To confirm the radical pathway, the deoxygenation reaction was examined by adding the TEMPO as a radical scavenger and neither of the products was obtained. These results demonstrate the reaction does proceed through radical deoxygenation (Scheme 6).

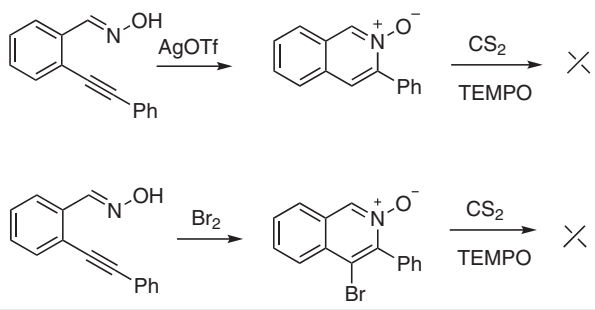

Scheme 6 Control experiment for the deoxygenation reaction process

In conclusion, we have opened a novel class of cyclization-deoxygenation reactions through the introduction of a $\mathrm{CS}_{2}$ as an efficient reagent for the synthesis of isoquinoline derivatives using 2-alkynylbenzaldoximes. ${ }^{16-18}$ Furthermore, in comparison to existing approaches in the literature, the use of cheap, commercially available carbon disulfide under mild reaction conditions are some advantages of this reported work.

\section{Conflict of Interest}

The authors declare no conflict of interest.

\section{Funding Information}

We thank the Alexander von Humboldt Foundation for the Linkage Research Group Program and K. N. Toosi University of Technology Research Affairs for support. 


\section{Supporting Information}

Supporting information for this article is available online at https://doi.org/10.1055/s-0040-1719870.

\section{References and Notes}

(1) (a) Nicolaou, K. C.; Koumbis, A. E.; Snyder, S. A.; Simonsen, K. B. Angew. Chem. Int. Ed. 2000, 39, 2529. (b) Bliznets, I. V.; Shorshnev, S. V.; Aleksandrov, G. G.; Stepanov, A. E.; Lukyanov, S. M. Tetrahedron Lett. 2004, 45, 9127. (c) Katritzky, A. R.; Lagowski, J. M. Chemistry of the Heterocyclic N-Oxides; Academic Press: New York, 1971.

(2) Chung, J. Y. L.; Cvetovich, R. J.; McLaughlin, M.; Amato, J.; Tsay, F.-R.; Jensen, M.; Weissman, S.; Zewge, D. J. J. Org. Chem. 2006, $71,8602$.

(3) Bernard, H.; Bülow, G.; Lange, U. E. W.; Mack, H.; Pfeiffer, T.; Schafer, B.; Seitz, W.; Zierke, T. Synthesis 2004, 2367.

(4) Campeau, L. C.; Stuar, D. R.; Leclerc, J. P.; Bertrand-Laperle, M.; Villemure, E.; Sun, H. Y.; Lasserre, S.; Guimond, N.; Lecavallier, M.; Fagnou, K. J. Am. Chem. Soc. 2009, 131, 3291.

(5) (a) Kim, K. D.; Lee, J. H. Org. Lett. 2018, 20, 7712. (b) Fukui, M.; Tanaka, A.; Kominami, H. Ind. Eng. Chem. Res. 2020, 59, 11412.

(6) Xu, P.; Xu, H. C. Synlett 2019, 30, 1219.

(7) (a) Daniher, F. A.; Hackley, B. E. J. Org. Chem. 1966, 31, 4267. (b) Olah, G. A.; Arvanaghi, M.; Vankar, Y. D. Synthesis 1980, 660. (c) Hayashi, E.; Ijima, C. J. Pharm. Soc. Jpn. 1962, 82, 1093.

(8) (a) Howard, J. E.; Olszewski, W. F. J. Am. Chem. Soc. 1959, 81, 1483. (b) Shirinian, V. Z.; Lonshakov, I. A.; Zakharov, A. V.; Lvov, A. G.; Krayushkin, M. M. Synthesis 2019, 414. (c) Kaneko, C.; Yamamori, M.; Yamamoto, A.; Hayashi, R. Tetrahedron Lett. 1978, 19, 2799.

(9) (a) Kokatla, H. P.; Thomson, P. F.; Bae, S.; Doddi, V. R.; Lakshman, M. K. J. Org. Chem. 2011, 76, 7842. (b) Gowda, N. B.; Rao, G. K.; Ramakrishna, R. A. Tetrahedron Lett. 2010, 51, 5690. (c) Ram, S. R.; Chary, K. P.; Iyengar, D. S. Synth. Commun. 2000, 30, 3511.

(10) (a) Kim, J.; Kim, S.; Kim, D.; Chang, S. J. Org. Chem. 2019, 84, 13150. (b) Jeong, J.; Lee, D.; Chang, S. Chem. Commun. 2015, 51, 7035. (c) Donck, S.; Gravel, E.; Shah, N.; Jawale, D. V.; Doris, E.; Namboothiri, I. N. RSC Adv. 2015, 5, 50865. (d) Park, E. S.; Lee, S. H.; Lee, J. H.; Rhee, H. J.; Yoon, C. M. Synthesis 2005, 3499. (e) Saini, A.; Kumar, S.; Sandhu, J. S. Synlett 2006, 395. (f) Fuentes, J. A.; Clarke, M. L. Synlett 2008, 2579.

(11) (a) Gupta, S.; Sureshbabu, P.; Singh, A. K.; Sabiah, S. J. Tetrahedron Lett. 2017, 58, 909. (b) Yadav, J. S.; Subba Reddy, B. V.; Muralidhar Reddy, M. Tetrahedron Lett. 2000, 41, 2663. (c) Bjørsvik, H.-R.; Gambarotti, C.; Jensen, V. R.; Rodríguez González, R. J. Org. Chem. 2005, 70, 3218. (d) Vorbrüggen, H.; Krolikiewicz, K. Tetrahedron Lett. 1983, 24, 5337. (e) Subbarao, K. P. V.; Reddy, G. R.; Muralikrishna, A.; Reddy, K. V.J. Heterocycl. Chem. 2014, 51, 1045. (f) Zhao, X.; Fan, W.; Miao, Z.; Chen, R. Synth. Commun. 2013, 43, 1714.

(12) Movassaghi, M.; Hill, M. D. Org. Lett. 2008, 10, 3485.

(13) (a) Deng, C.; Lam, W. H.; Lin, Z. Organometallics 2017, 36, 650. (b) Hughes, G.; Bryce, M. R. J. Mater. Chem. 2005, 15, 94. (c) Solomon, V. R.; Lee, H. Curr. Med. Chem. 2011, 18, 1488. (d) Kimyonok, A.; Wang, X. Y.; Weck, M. J. Macromol. Sci., Polym. Rev. 2006, 46, 47. (e) Thurston, D.; Rotella, D.; Martinez, A. Privileged Scaffolds in Medicinal Chemistry. Design, Synthesis, Evaluation; Bräse, S., Ed.; Royal Society of Chemistry: London, 2016. (f) Araujo, D. R.; Goulart, H. A.; Barcellos, A. M.; Cargnelutti, R.; Lenardão, E. J.; Perin, G. J. Org. Chem. 2021, 86, 1721. (g) Gujjarappa, R.; Vodnala, N.; Malakar, C. C. Adv. Synth. Catal. 2020, 362, 4896.

(14) (a) Nikbakht, A.; Balalaie, S.; Breit, B. Org. Lett. 2019, 21, 7645. (b) Hayatgheybi, S.; Khosravi, H.; Zahedian Tejeneki, H.; Rominger, F.; Bijanzadeh, H. R.; Balalaie, S. Org. Lett. 2021, 23, 3524 .

(15) (a) McKee, M. L.; Wine, P. H. J. Am. Chem. Soc. 2001, 123, 2344. (b) Murrells, T. P.; Lovejoy, E. R.; Ravishankara, A. R. J. Phys. Chem. 1990, 94, 2381. (c) Zeng, Z.; Altarawneh, M.; Dlugogorski, B. Z. Chem. Phys. Lett. 2017, 669, 43.

(16) General Procedure for the Synthesis of 2-Alkynylbenzaldoximes 1a-i

2-Alkynylbenzaldehyde ( $2.0 \mathrm{mmol}$ ) (synthesized following previously reported procedures $\left.{ }^{14}\right)$, hydroxylamine hydrochloride ( $3 \mathrm{mmol}, 1.5$ equiv), sodium acetate $(4.0 \mathrm{mmol}, 2.0$ equiv), and $\mathrm{CH}_{3} \mathrm{CN}(10 \mathrm{~mL})$ were added sequentially into a $25 \mathrm{~mL}$ flask and the mixture stirred at room temperature for $12 \mathrm{~h}$ (monitored by TLC). After completion of reaction, the solvent was evaporated to afford the crude product. Finally, the pure corresponding 2alkynylbenzaldoximes $\mathbf{1 a - i}$ were obtained by flash chromatography (silica gel, eluent: $n$-hexane/EtOAc, 4:1).

(17) General Procedure for the Synthesis of Isoquinolines 2a-i in the Presence of AgOTf and $\mathrm{CS}_{\mathbf{2}}$

To a solution of 2-alkynylbenzaldoximes $(0.2 \mathrm{mmol})$ in DMF (2 $\mathrm{mL}$ ) was added $\mathrm{AgOTf}(10 \mathrm{~mol} \%$ ), and the mixture was stirred at $60{ }^{\circ} \mathrm{C}$ in an oil bath for $30 \mathrm{~min}$, leading to the isoquinolines $\mathrm{N}$ oxide (monitored by TLC). Then $\mathrm{CS}_{2}$ (1.2 equiv) was added, and the reaction mixture was stirred at $60{ }^{\circ} \mathrm{C}$ for $6 \mathrm{~h}$. Upon completion of the reaction (as indicated by TLC), the reaction mixture was extracted with $\mathrm{H}_{2} \mathrm{O}(10 \mathrm{~mL})$ and EtOAc $(3 \times 10 \mathrm{~mL})$. The combined organic extracts were dried over anhydrous $\mathrm{Na}_{2} \mathrm{SO}_{4}$, filtered, and concentrated under reduced pressure. The crude residue was purified using column chromatography (silica gel, eluent: $n$-hexane/EtOAc, 5:1) to afford the corresponding isoquinolines $\mathbf{2 a - i}$ (70-95\%).

3-Phenylisoquinoline (2a)

Yellow solid (39 mg, yield 95\%, mp 48-49 ${ }^{\circ} \mathrm{C}$ ), $R_{f}=0.35$ ( $n$-hexane/EtOAc, 5:1). ${ }^{1} \mathrm{H}$ NMR $\left(300 \mathrm{MHz}, \mathrm{CDCl}_{3}\right): \delta=9.35(\mathrm{~s}, 1 \mathrm{H}, \mathrm{H}-1$ isoquinoline), 8.15 (d, $J=7.2 \mathrm{~Hz}, 2 \mathrm{H}, \mathrm{HAr}), 8.06(\mathrm{~s}, 1 \mathrm{H}, \mathrm{HAr}$ ), $7.98(\mathrm{~d}, J=8.0 \mathrm{~Hz}, 1 \mathrm{H}, \mathrm{HAr}), 7.86(\mathrm{~d}, J=8.0 \mathrm{~Hz}, 1 \mathrm{H}, \mathrm{HAr}), 7.68(\mathrm{t}$, $J=7.2 \mathrm{~Hz}, 1 \mathrm{H}, \mathrm{HAr}$ ), 7.57 (t, $J=7.3 \mathrm{~Hz}, 1 \mathrm{H}, \mathrm{HAr}), 7.53(\mathrm{t}, J=7.3$ $\mathrm{Hz}, 2 \mathrm{H}, \mathrm{HAr}), 7.43(\mathrm{t}, J=7.3 \mathrm{~Hz}, 1 \mathrm{H}, \mathrm{HAr}) .{ }^{13} \mathrm{C}\left\{{ }^{1} \mathrm{H}\right\}$ NMR $(75$ $\left.\mathrm{MHz}, \mathrm{CDCl}_{3}\right): \delta=152.4,151.2,139.6,136.6,130.5,128.8,128.5$, 127.7, 127.5, 127.1, 127.0, 126.9, 116.5. HRMS (ESI-TOF): $\mathrm{m} / \mathrm{z}$ $[\mathrm{M}+\mathrm{H}]^{+}$calcd for $\mathrm{C}_{15} \mathrm{H}_{12} \mathrm{~N}$ : 206.0957; found: 206.0961.

(18) General Procedure for the Synthesis of 4-Bromo-3aryl(alkyl)isoquinolines 3a-g Using $\mathrm{Br}_{2}$ and $\mathrm{CS}_{2}$

A mixture of 2-alkynylbenzaldoxime $(0.2 \mathrm{mmol}), \mathrm{NaHCO}_{3}(1.2$ equiv), and $\mathrm{Br}_{2}$ (1.2 equiv) in $\mathrm{DMF}(2 \mathrm{~mL})$ was stirred at room temperature for $30 \mathrm{~min}$. After preparation of the 4-bromo-3aryl(alkyl)isoquinoline $\mathrm{N}$-oxide (monitored by TLC), $\mathrm{CS}_{2}(1.2$ equiv) was added, and the reaction mixture was allowed to stir at $60{ }^{\circ} \mathrm{C}$ until the reaction was complete (TLC monitoring, about $3.5 \mathrm{~h})$. The crude mixture was extracted with $\mathrm{H}_{2} \mathrm{O}(10 \mathrm{~mL})$ and EtOAc $(3 \times 10 \mathrm{~mL})$, and the combined organic extracts were dried over anhydrous $\mathrm{Na}_{2} \mathrm{SO}_{4}$, filtered, and the solvent was removed under reduced pressure. The residue was purified by column chromatography (silica gel, eluent: $n$-hexane/EtOAc, $5: 1$ ) to give the corresponding 4-bromo-3-aryl(alkyl)isoquinoline $3 \mathbf{a}-\mathbf{g}(65-89 \%)$. 
4-Bromo-3-phenylisoquinoline (3a)

Brown solid (50 mg, yield $89 \%$, mp $47{ }^{\circ} \mathrm{C}$ ); $R_{f}=0.30$ ( $n$-hexane/EtOAc, 5:1). $\left.1 \mathrm{H} \mathrm{NMR} \mathrm{(300} \mathrm{MHz,} \mathrm{CDCl}_{3}\right): \delta=9.25(\mathrm{~s}, 1 \mathrm{H}, \mathrm{H}-1$ isoquinoline), 8.35 (d, $J=8.6 \mathrm{~Hz}, 1 \mathrm{H}, \mathrm{HAr}), 8.02(\mathrm{~d}, J=8.1 \mathrm{~Hz}, 1$ $\mathrm{H}, \mathrm{HAr}$ ), 7.75 (d, $J=6.4 \mathrm{~Hz}, 1 \mathrm{H}, \mathrm{HAr}$ ), 7.56-7.48 (m, $3 \mathrm{H}, \mathrm{HAr}$ ),
7.39-7.32 (m, $3 \mathrm{H}, \mathrm{HAr}) .{ }^{13} \mathrm{C}\left\{{ }^{1} \mathrm{H}\right\} \mathrm{NMR}\left(75 \mathrm{MHz}, \mathrm{CDCl}_{3}\right): \delta=$ $151.1,148.8,132.5,132.0,131.6,129.9,129.5,128.7,128.4$, 128.0, 127.0, 125.2, 118.4. HRMS (ESI-TOF): $m / z[\mathrm{M}+\mathrm{H}]^{+}$calcd for $\mathrm{C}_{15} \mathrm{H}_{11}{ }^{79} \mathrm{BrN}$ : 284.0738; found: 284.0741. 